\title{
Review \\ pH-Sensitive Biomaterials for Drug Delivery
}

\author{
Shijie Zhuo ${ }^{1,+}{ }^{,}$Feng Zhang ${ }^{1,+}$, Junyu $\mathrm{Yu}^{1,+}{ }^{1}$, Xican Zhang ${ }^{1, *}$, Guangbao Yang ${ }^{2}$ and \\ Xiaowen Liu ${ }^{1, *}$
}

1 Clinical Translational Center for Targeted Drug, Department of Pharmacology, School of Medicine, Jinan University, Guangzhou 510632, China; caracheuk@stu2018.jnu.edu.cn (S.Z.); zf1411947710@stu2018.jnu.edu.cn (F.Z.); yujunyu@stu2018.jnu.edu.cn (J.Y.)

2 Collaborative Innovation Center of Radiation Medicine of Jiangsu Higher Education Institutions, State Key Laboratory of Radiation Medicine and Protection, School of Radiation Medicine and Protection \& School for Radiological and Interdisciplinary Sciences (RAD-X), Soochow University, Suzhou 215123, China; yangguangbao@nwpu.edu.cn

* Correspondence: zhangxican316@stu2017.jnu.edu.cn (X.Z.); xwliu231@jnu.edu.cn (X.L.)

+ These authors contributed equally to this work.

Academic Editor: Jesús Martínez de la Fuente

Received: 29 September 2020; Accepted: 23 November 2020; Published: 30 November 2020

\begin{abstract}
The development of precise and personalized medicine requires novel formulation strategies to deliver the therapeutic payloads to the pathological tissues, producing enhanced therapeutic outcome and reduced side effects. As many diseased tissues are feathered with acidic characteristics microenvironment, $\mathrm{pH}$-sensitive biomaterials for drug delivery present great promise for the purpose, which could protect the therapeutic payloads from metabolism and degradation during in vivo circulation and exhibit responsive release of the therapeutics triggered by the acidic pathological tissues, especially for cancer treatment. In the past decades, many methodologies, such as acidic cleavage linkage, have been applied for fabrication of $\mathrm{pH}$-responsive materials for both in vitro and in vivo applications. In this review, we will summarize some $\mathrm{pH}$-sensitive drug delivery system for medical application, mainly focusing on the $\mathrm{pH}$-sensitive linkage bonds and $\mathrm{pH}$-sensitive biomaterials.
\end{abstract}

Keywords: $\mathrm{pH}$ sensitive biomaterials; $\mathrm{pH}$ sensitive linkage bonds; drug delivery system

\section{Introduction}

Biomaterials have been widely developed as the carriers of various drugs for medical application [1-4] — of which $\mathrm{pH}$-sensitive biomaterials represent a promising species, which can perform deformation or degradation after exposure to external acidic or alkaline environments. The $\mathrm{pH}$-sensitive characteristics enable the changes in intramolecular or intermolecular forces of the formulations in external $\mathrm{pH}$ conditions, resulting in a trigger release of payloads [5-7]. There are basically two major different mechanisms to release the loading drugs in $\mathrm{pH}$-sensitive drug delivery systems [8]: one is releasing the medicines generated from the changed hydrophobicity or a charge of carrier molecules by protonation/deprotonation induced by the external $\mathrm{pH}$ variation. The other is releasing the loading drugs based on $\mathrm{pH}$-sensitive dynamic chemical bond cleavage [8].

Cancer is one of the leading causes of human death around the world $[9,10]$. In the past decades, nanomaterials based on the tumor microenvironment (TME) has been proposed to be a promising approach to improve the efficiency of cancer therapy [11,12]. TME constructs the external environment of tumor cells, which is closely related to the occurrence and metastasis of tumors [13,14]. The tumor microenvironment is composed of tumor cells, stromal cells, cytokines, and matrix. Due to the rapid growth and high volume expansion of tumor tissues, the tumor microenvironment is characterized by low oxygen [15-17] and mild acidity $\mathrm{pH}(6.5-6.9)$ [18]. With the better understanding of tumor 
cell biology, the tumor microenvironment is of great significance for the formation, development, metastasis, and other processes of tumors $[19,20]$. These abnormal microenvironments in return also provide the unique parameters for the designing of intelligent biomaterials for cancer therapy [21,22]. For control release of the therapeutics, many $\mathrm{pH}$-responsive formulations have been designed based on the tumor acidic environment $[23,24]$.

pH-sensitive biomaterials have been developed rapidly in the past decades and have made great achievements. As shown in Figure 1, we have summarized the number of publications about pH-sensitive biomaterials in the past 20 years (Figure 1), which increases every year. In this review, we focus on the $\mathrm{pH}$-responsive linkage bonds and $\mathrm{pH}$-sensitive nanomaterials for medical applications, especially for cancer therapy. Firstly, we summarize some common pH-sensitive biomaterials based on different types of $\mathrm{pH}$-sensitive bonds. In the following, we summarize $\mathrm{pH}$-sensitive nanomaterials for drug delivery purposes.

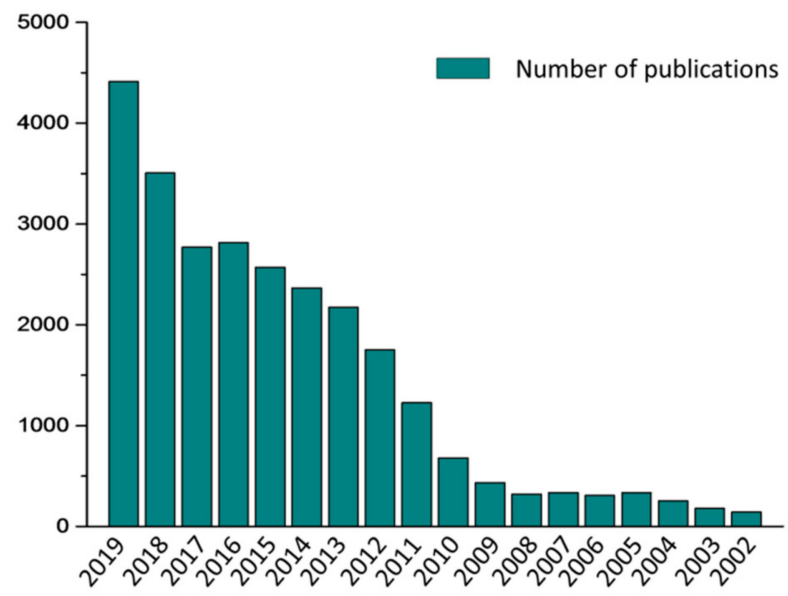

Figure 1. Statistics on the number of published journals on $\mathrm{pH}$-sensitive biomaterials over the past 20 years.

\section{2. pH-Sensitive Bonds}

The functionalization of biomaterials, which are covalently bonded to drug molecules, is the most common way to obtain intelligent biomaterials [25-29]. This type of carrier has high stability and can effectively prevent the premature release of drugs under physiological conditions [30]. However, in order to deliver drugs effectively, responsive biomaterials are showing great prospect [31-33]—of which, $\mathrm{pH}$-responsive biomaterials equipped with acidic trigger release capacity have been widely used for the purpose. The $\mathrm{pH}$-responsive biomaterials are expected to store the drugs in normal $\mathrm{pH}$ and release the drugs in a specific $\mathrm{pH}$ condition. To achieve this, $\mathrm{pH}$-sensitive chemical bonds can be anchored within the drug carriers, and the configuration of the carriers can be deformation through the cleavage of the dynamic chemical bonds, so as to control release the payloaded drugs [8]. In this section, we will introduce the commonly used pH-sensitive chemical bonds (Table 1). 
Table 1. pH-sensitive chemical bonds and release mechanisms in the acidic conditions.

Amine

\subsection{Imine Bonds}

Imines are formed by condensation of primary amine with aldehydes or ketones. Imine bond can be hydrolyzed under weak acid conditions ( $\mathrm{pH} \sim 6.8$, near the $\mathrm{pH}$ of solid tumors), but its stability in physiological $\mathrm{pH}$ environment can be improved [34-39].

Yang et al. synthesized a polymer poly(ethylene glycol)-cholic acid grafted poly-L-lysine (PEG-PLL-CA) anchored with benzoimide, and demonstrated that polycationic micelles formed by self-assembly of PEG-PLL-CA could function as the carriers of therapeutics for tumor therapy with pH-responsive characteristics [40]. The imine bond is liable to hydrolyze under acidic conditions which can also be used to modify the surface of the nanocarriers [41], and the acid-sensitive release of the drugs on the carrier can be realized triggered in the acidic environment. Xu et al. synthesized the pentaerythritol tetra(3-mercaptopropionate)-allylurea-poly(ethylene glycol) (PETMP-AU-PEG) anchored with imide bonds. They demonstrated that PETMP-AU-PEG loaded with DOX were highly stable in the neutral environment. While under the environment of weak acid, the formulation can be a responsive release of DOX for antitumor outcomes by cleavage of imide bond [42].

\subsection{Hydrazone Bonds}

Hydrazone is formed by condensation of aldehydes, ketones, or hydrazine. Similar to imine bonds, the hydrazone bonds are also a class of covalent bonds which are acidic responsive [43-47]. As hydrazone bonds are easily hydrolytic under acidic conditions, they have been widely utilized in the construction of acidic sensitive carriers for responsive formulations [48,49].

Rihova et al. applied N-(2-hydroxypropyl) methylacrylamide (HPMA) as the backbone to prepare HPMA-DOX formulations anchored with hydrazine bonds, and they reported that the formulations could increase the in vivo circulation time of DOX for optimal targeting accumulate in the tumor and afterwards responsive release triggered by the acidic tumor environment [50]. Song et al. first synthesized the polymer PEG-DiHyd-PLA containing the hydrazone bond by open-loop polymerization, and then the polymeric micelles were formed by self-assembly for loading DOX. They demonstrated that the formulations could release DOX rapidly and completely under the specific acidic conditions of tumor tissues [51]. 


\subsection{Oxime Bonds}

Oxime is formed by condensation of aldehydes, ketones, or hydroxylamine. Oxime can hydrolyze into aldehydes, ketones, and hydroxylamines under acidic conditions [52,53]. A potential advantage of using oxime bond for tumor-targeted nanocarriers is the tunability of its acid lability by facile variation of the substituents [54].

Zhu and colleagues described a polymeric drug carrier system by self-assembly of the triblock copolymer (PEG-OPCL-PEG) which were synthesized by conjugating of hydrophilic poly(ethylene glycol) (PEG) and hydrophobic oxime-tethered polycaprolactone (OPCL), which was successfully prepared by reacting OPCL ligating with aldehyde-terminated PEG (PEG-CHO). During the self-assembly process, DOX as a drug model was loaded within the PEG-OPCL-PEG micelles. They demonstrated that the release rate of DOX in tumor tissue was significantly faster than in normal tissue, as a result of the acidic responsive of anchored oxime linkages within the micellers [53]. In another work, Zhu and colleagues described a flower micelle formulated by self-assembly of backbone-cleavable triblock copolymer polycaprolactone-oxime-poly(ethylene glycol)-oximepolycaprolactone (PCL-OPEG-PCL) in aqueous solution, during which the DOX were encapsulated within the micelles in high efficiency. In addition, the DOX loaded micelles had good stability in a neutral environment in vitro studies, but, under the condition of weak acid, DOX could be quickly released for the $\mathrm{pH}$ responsive characteristics and thus perform excellent antitumor outcomes [55].

\subsection{Amide Bonds}

Amide bond is formed by the substitution of the hydroxyl group in the carboxylic acid group by amino groups or hydrocarbon amino groups [53,56,57]. Amide bond can also be cleavage under acidic conditions [58-62], which are most widely used for designing pH-responsive formulations.

$\mathrm{Gu}$ et al. synthesized pH-sensitive polymeric micelle (mPEG-pH-PCL) through self-assembly of methoxy poly(ethylene glycol)-b-poly( $\epsilon$-caprolactone) copolymer anchored with citraconic amide as a pH-sensitive bond, and DOX were efficiently encapsulated in the micelle during assembly. They demonstrated that the DOX released from mPEG-pH-PCL micelles in pH 5.5 solution was much faster than that of in $\mathrm{pH} 7.4$, indicating a beneficial characteristic for drug targeting release in acidic tumors [63]. Forrest et al. used amide bonds to connect hyaluronic acid (HA) with DOX to form the HA-DOX conjugate. In the blood neutral environment, HA-DOX has good stability and biocompatibility during the circulation process, thus reducing dose-limiting cardiac toxicity and minimal toxicity observed in other normal tissues. However, once the therapeutic conjugation accumulated in the acidic environment of tumor tissue, the acidic hydrolysis of amide bond enabled DOX specific release, thus achieving better therapeutic effects [64].

\subsection{Acetals}

Acetals (including ketals) are promising acid-sensitive linkages for responsive formulations due to their sensitive hydrolysis with each unit of $\mathrm{pH}$ decrease $[65,66]$. Acetals are formed by condensation of aldehyde and alcohols. Under acidic conditions, acetal can be hydrolyzed into aldehyde and alcohols [67].

Zhong et al. conjugated acid biodegradable poly(acetal carbamate) (PAU) into a three block copolymer (PEG-PAU-PEG) and formulated to micelles by self-assembly for pH-triggered intracellular delivery of DOX. The three-block copolymer formed micelles had no cytotoxicity and performed good stability in the physiological pH. However, DOX could be triggered release in the acidic cytoplasm after uptake by endocytosis and induce apoptosis of cancer cells [68]. Pu and colleagues prepared tumor-pH-sensitive polymeric microspheres by using multi-block polyl-lactide (PLLA) with acetal bond as the backbone for efficient loading DOX. They reported better antitumor efficiency and prolonged life-span after intratumorally injection of the micelles compared to other control groups [69]. 


\subsection{Orthoester}

Orthoester is a functional group containing three alkoxy groups on the same carbon atom. Orthoester can be hydrolyzed into carboxylic acid and alcohol under acidic conditions [70].

Park et al. assembled micelles with copolymers bearing an acid-sensitive orthoester linkage, which composed of hydrophilic PEG and hydrophobic poly( $\gamma$-benzyl L-glutamate) (PBLG) and DOX. The DOX loaded polymeric micelles were stable under neutral conditions but could trigger the release of DOX for efficient therapy in the acidic tumor due to the acidic cleavage of orthoester [71].

\section{3. pH-Sensitive Nanomaterials}

In recent years, many administration routes have been widely developed for the medical application, and integrating the novel material engineering technologies with optimal administration route would enable their enhanced therapeutic efficiency and reduced side effects [72-77]. In terms of convenience, oral administration has great advantages. However, since drugs need to pass through the digestive tract during oral administration, and then arrive at the duodenum, jejunum, and ileum. The $\mathrm{pH}$ values in different parts of the gastrointestinal tract are different, that is, the stomach cavity is acidic, the $\mathrm{pH}$ range is $1-3$, and the duodenum is alkaline [78]. When a drug enters the gastrointestinal tract by oral administration, the drug will be exposed to a series of acidic environments and biological enzymes, which may be degraded or inactivated. The tumor microenvironment also has features with acidic and other abnormal characteristics which may suppress the bioactivity of delivered drugs [79]. These required the novel drug carriers which can protect the drugs from degradation and metabolisms prior to their final acting places and triggered release of the therapeutic payloads in the abnormal pathological tissues according to the $\mathrm{pH}$ gradients or other conditions.

Nanomaterials for drug delivery have broad application prospects [41,80-86]. For example, the nanoparticles encapsulated with drug molecules can isolate drugs and environments that may degrade or inactivate drugs, providing a relative stable environment for drug molecules with expected bioavailability while passing through the complex in vivo environment. At the same time, since the nanoparticles allow them to penetrate the endothelium and capillary tubes, the use of nanoparticles to deliver drugs to target cells in inflammatory sites may be considered [87]. These carriers can release drugs in the extracellular environment, or within the cell through endocytosis. $\mathrm{pH}$-responsive characteristics can be added into the nanoparticles which can be degradation or deformation under specific conditions, such as acidic conditions, thereby releasing the encapsulated drugs and acting on a specific location. After the changes of nanoparticles, the release of drugs from nanocarriers can be triggered based on the change of $\mathrm{pH}$ [88-91]. Compared with the ordinary nanoparticles, advantages of $\mathrm{pH}$-responsive nanoparticles lie in applying acidic $\mathrm{pH}$ as a kind of external stimuli, resulting in the changes of drug release kinetics [92-94]. Herein, we present an overview of pH-sensitive nanomaterials [95] including hydrogel, liposomes, and polymer micelles.

\subsection{Hydrogels}

Hydrogels are composed of polymers that are crosslinked into a three-dimensional network [96-98]. Hydrogels can be made of synthetic or natural polymers and they are capable of imbibing large quantity of water or fluids $[99,100]$. There are a large number of hydrophilic groups on the polymer chain, such as $-\mathrm{NH}_{2},-\mathrm{OH},-\mathrm{COOH}$, and $-\mathrm{SO}_{3}$. With the increase of capillary action and osmotic pressure, hydrogels are relatively insoluble in the surrounding media due to the cross-linking between the polymer chains. The cross-linking in hydrogels is both physical (hydrogen bonding) and chemical (covalent bonding between functional groups) (Figure 2a). Hydrogel was first proposed in the 1960s by Wichterle and Lim using a hydrophilic network of poly(2-hydroxyethyl methacrylate) in contact lenses [101,102]. Hydrogels are valuable due to their easy fabrication process, small size, mouldability, immunity to electromagnetic radiation, and biocompatibility [100]. The physical characteristics of hydrogels can be tuned to provide specifications to match various applications in drug delivery 
systems or other aspects [103-108]. pH-responsive hydrogels been developed greatly over the past few years and shown to be very useful in biomedical applications, especially like targeted cancer treatment [109-111]. The use of pH-sensitive hydrogels can prolong drug release availability, and the synthesis of $\mathrm{pH}$-sensitive hydrogels is also quick and cost-effective. In addition, $\mathrm{pH}$-sensitive hydrogels have been investigated frequently for delivery of peptide drugs [112,113].

Currently, the use of $\mathrm{pH}$-sensitive hydrogels for cancer therapy has been investigated as improving the efficiency of the released drugs [114-118]. Polymers commonly used to study pH-responsive hydrogels including polyacrylate, poly ( $N$-isopropyl acrylamide), polyacrylate, $n$-vinyl caprolactam, sodium alginate, and carrageenan $[119,120]$.
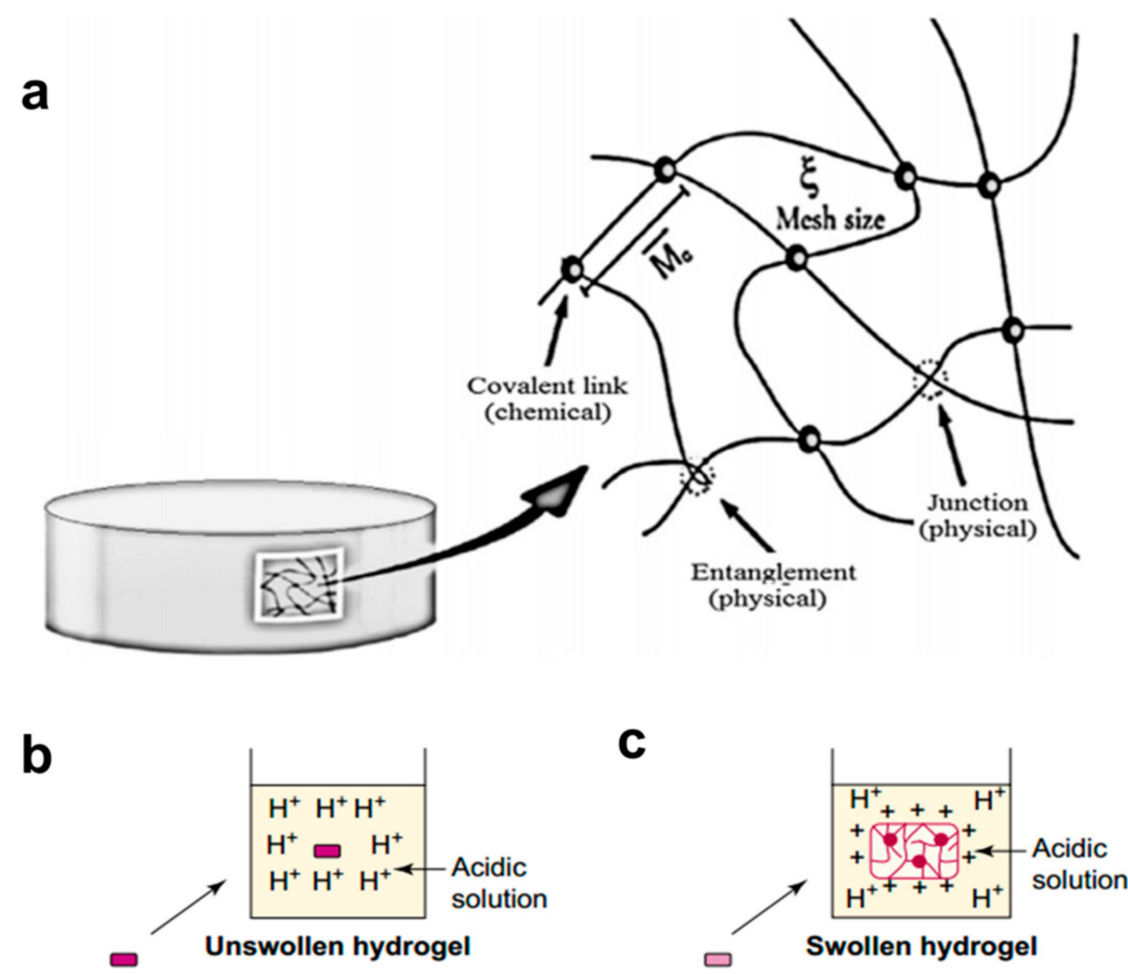

Anionic hydrogel

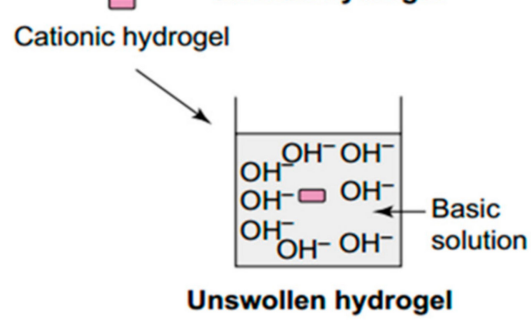

Figure 2. Hydrogels: (a) structural chemistry of a hydrogel [121]; (b,c) the pH-responsive swelling of anionic (b) and cationic (c) hydrogels [122].

Some traditional hydrogels require the use of different substances, such as poly(N-isopropyl acrylamide) and poly(acrylic acid) attached to the PVF skeleton, fabricating hydrogels with dual temperature and $\mathrm{pH}$ response [119]. Alternatively, bivalent copper can be used in conjunction with alginate to form hydrogels by gel spheroidization. It is worth mentioning that the encapsulation system made by this method has been proved to maintain their structural integrity at $\mathrm{pH} 1.2$, and the contents can only be released slowly at $\mathrm{pH}>5$, which suggests the stability of the encapsulation system under the conditions of simulated stomach, and release the contents slowly under the conditions of intestinal tract $[123,124]$. In addition to the traditional hydrogels, there are also novel hydrogels, such as gelation by crosslinking of poly (vinyl pyrrolidone) polymer and rotonic acid under $\gamma$-radiation [122]. The drug release rate from the gelation in acidic medium is much lower, while the release rate in neutral medium 
is faster. Therefore, similar to the former, it has the potential to act as a drug carrier to protect the release of drugs through the stomach in the intestinal tract. Some hydrogels also need to improve the stability of the pore wall to prevent swelling, such as the use of silica nanocomposites on top of polyn-isopropyl acrylamide [122]. Furthermore, the majority of the pH-responsive hydrogels [125] relies on the side chain by ionization, namely through the protonation of cationic groups or anionic groups, or the electric network with the surrounding environment, forming electrostatic repulsion [121] (Figure 2b,c).

In addition, dual temperature and $\mathrm{pH}$-responsive hydrogels or dual magnetic and $\mathrm{pH}$-responsive hydrogels were also expanding their medical application, allowing for more precise drug release behavior. Ren et al. synthesized the supramolecular hydrogels hybridized with magnetic nanoparticles (MNPs) and gold nanoparticles (AuNPs). These hybrid hydrogels which stimulated by temperature and pH showed reversible sol-gel transition [126] (Figure 3). There are also pH-responsive cellulose gels used as wound dressings based on hydrogels that could self-degrade on the mild acidic skin surfaces and have the ability to self-heal, which have broad application prospects. Amanda et al. showed that surface functionalization of cellulose nanocrystals (CNCs) with amine (CNC-NH$)$ moieties enabled the CNCs with $\mathrm{pH}$-responsive characteristics. The transition to hydrogels as observed at higher $\mathrm{pH}$ degraded into dispersion aqueous at low $\mathrm{pH}$. This could be incorporated into a poly(vinyl acetate) matrix to yield mechanically adaptive $\mathrm{pH}$-responsive nanocomposite films [127] (Figure 4).

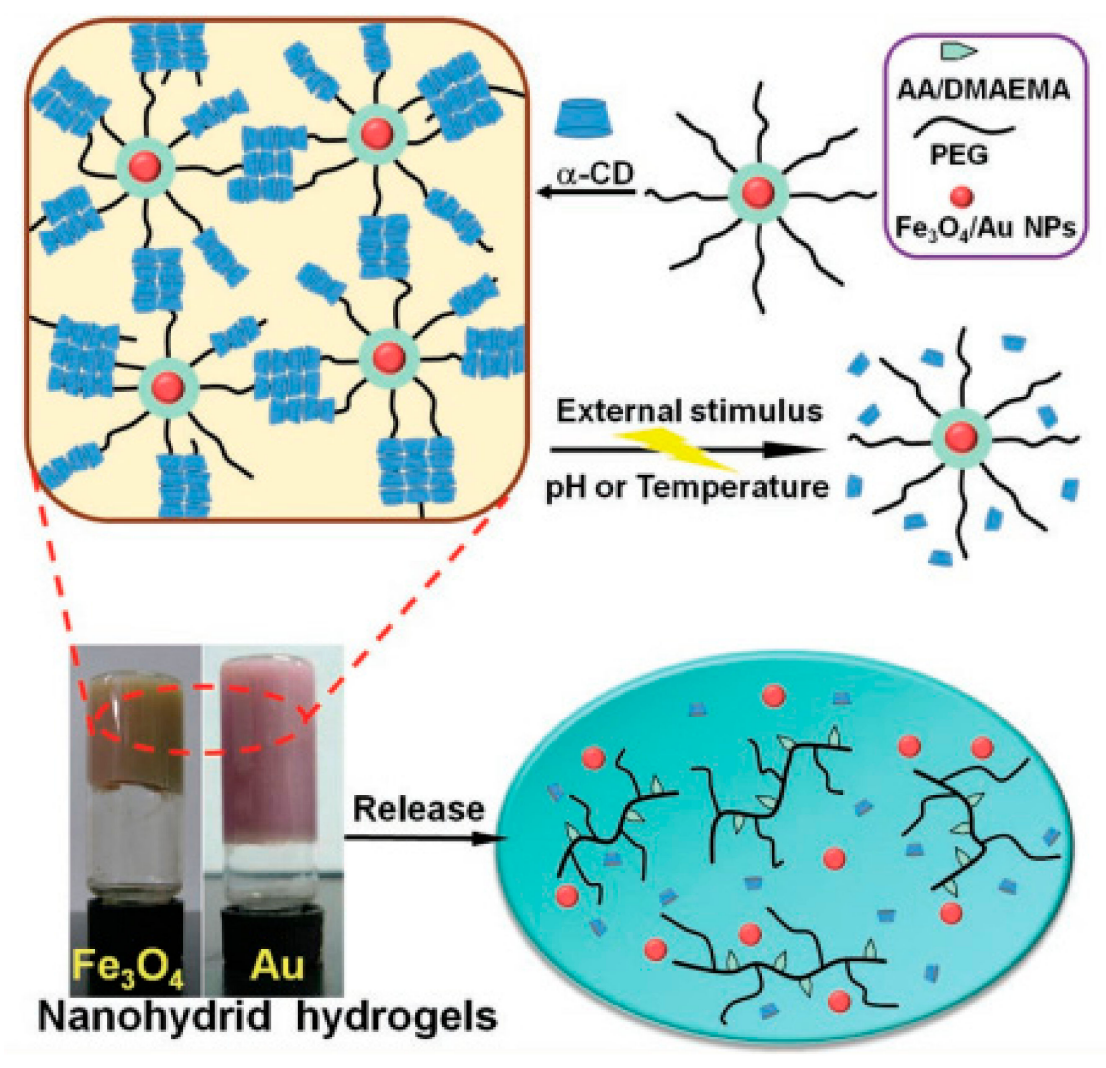

Figure 3. Synthesis of the supramolecular hydrogels hybridized with inorganic MNPs and AuNPs and its release [126]. 


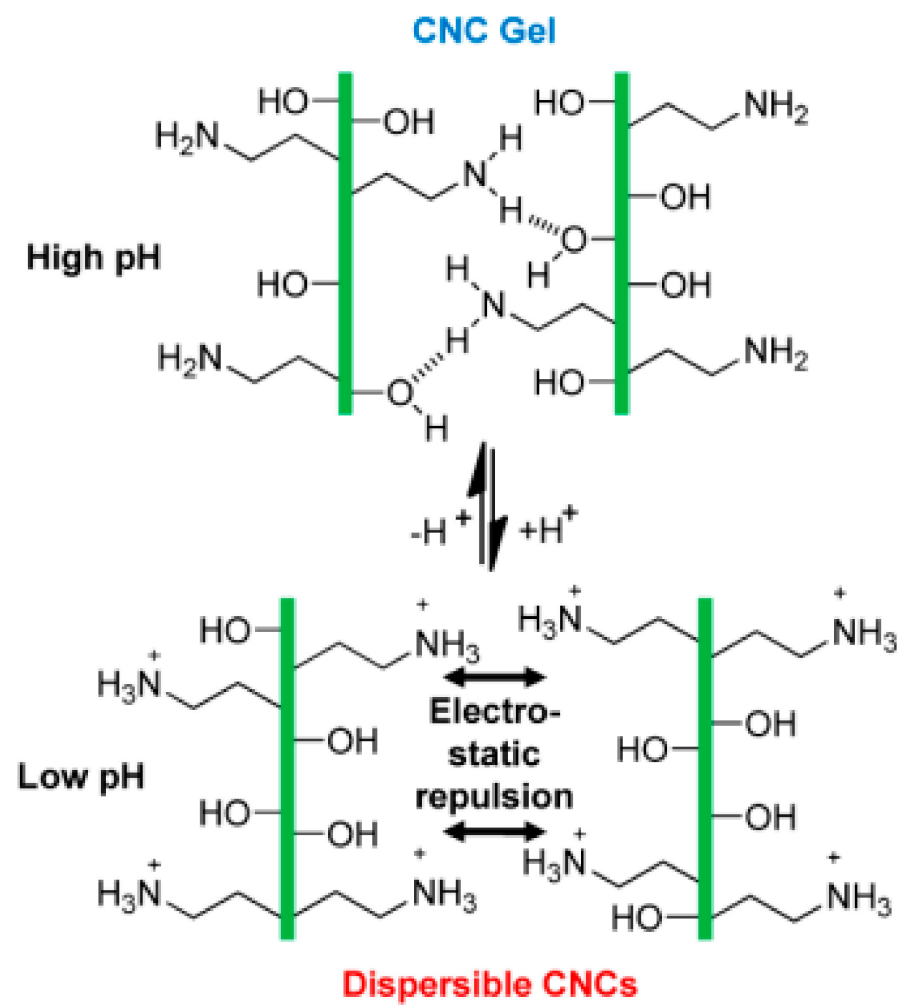

Figure 4. Schematic representation of the proposed interactions of $\mathrm{CNC}-\mathrm{NH}_{2}$ at high and low $\mathrm{pH}$ [127].

\subsection{Liposomes}

In the 1960s, the first lipid-based vesicles for drug delivery was reported [128-130]. Liposomes [131] are a kind of biomimetic nanosome with a hollow structure consisting of phospholipid bilayers (Figure 5). The ability of liposomes to encapsulate both hydrophilic and hydrophobic drugs, coupled with their biocompatibility and biodegradability, make liposomes attractive vehicles in the field of drug delivery [132-135]. Liposomes are frequently used for delivery of drugs, antigens, vaccines [136], DNA, and/or diagnostic units [137-141]. The liposomes could be internalized by cells through different endocytic pathways and effectively deliver the encapsulated drugs into the cell matrix [128,129,142-145]. For their optimal in vivo application [146], the surface of liposomes can be functionalized with various hydrophilic polymers, such as PEG, to minimize reticuloendothelial system recognition and absorption $[147,148]$. The diameter of liposomes enables passive accumulation in tumor tissue for antitumor effect through the enhanced permeability and retention effect (EPR) [149-152]. The composition of liposomal systems can be easily modified to facilitate triggered release in response to environmental conditions. For example, $\mathrm{pH}$-responsive liposomes are specifically designed to control the drug release in response to the acidic tumor microenvironment [153].

pH-responsive liposomes [154,155] represent a promising carrier for the loading of drugs for medical applications [153]. One common method to prepare $\mathrm{pH}$-responsive liposomes is to use $\mathrm{pH}$-sensitive components to fabricate liposomes. When these responsive units introduced into the liposomes, the liposome can be transformation or degradation in the acidic endosomes or environments of tumors, resulting in the trigger release of payload with $\mathrm{pH}$-responsive behaviors [156]. In addition to the instability caused by $\mathrm{pH}$-sensitive components, the stability of liposomes can also be affected by the integrated hydrophobic chains. These $\mathrm{pH}$-liposomes have some significant advantages, such as low toxicity, simple preparation, and good biocompatibility as a result of the biocompatible degradable components $[157,158]$. 


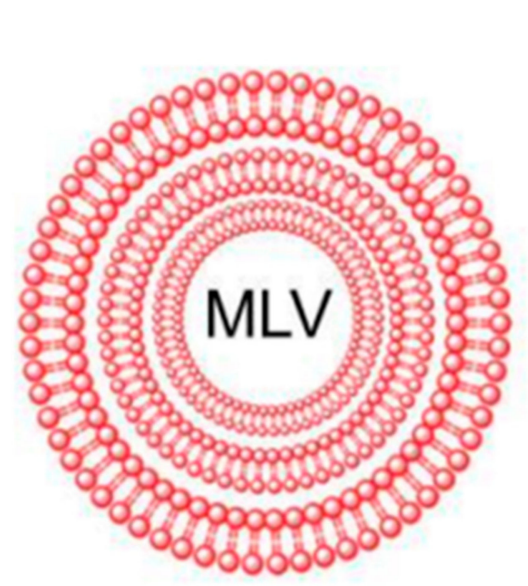

1-5 $\mu \mathrm{M}$

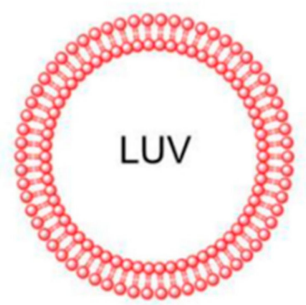

$100-250 \mathrm{~nm}$

\section{Not to scale}

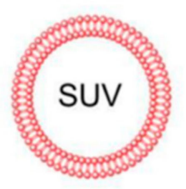

20-100 nm

Figure 5. Classification of liposomes based on the lamellarity: Multilamellar Vesicles (MLV) with many lipid bilayers ranges from 1-5 $\mu \mathrm{m}$ in size. Large Unilamellar Vesicle (LUV) is about 100-250 nm with single lipid bilayer. Small Unilamellar Vesicles (SUV) with size range 20-100 nm consists of a single phospholipid bilayer (reused with modification) [157].

pH-responsive liposomes [159] can function as the carrier of anti-tumor therapeutics for targeting delivery to the tumor and trigger release of the encapsulated drugs in the acidic environment. However, their use for in vivo application also presents great challenges. In general, the size of liposomes used for in vivo application is usually between 50 and $450 \mathrm{~nm}$, and the liposomes within this diameter scale are easily removed by the RES system during blood circulation $[157,160]$. At the same time, although their structure and composition are similar to that of the cell membrane, liposomes are still easily recognizable as the antigens, and faced with the in vivo clearance by the immune system. To improve their in vivo fate for better therapeutic outcome, various surface modification strategies are developed such as introducing the PEG chains to the outside surface of liposomes, so as to prolong their in vivo circulation time [130,157,161,162] (Figure 6). In addition to the therapeutic purpose, pH-responsive liposomes are also becoming important tools for vaccine delivery. These liposomes are used to deliver small peptides or antibodies to produce an effective immune response and reduce their toxicity. Kim and colleagues successfully transferred the $\mathrm{pH}$-sensitive liposomes loaded with cytotoxic T lymphocytes epitope peptides for tumor therapy, which resulted from the induced effective antigen-specific CTL responses after the responsive release of peptides in the acidic tumor [163].

a<smiles>CCCCCCCCCCCCCCCCCCCCCCCCC(=O)OCC(COP(=O)([O-])OCC[N+](C)(C)C)OC(=O)CCCCCCCCCCC</smiles>

b<smiles>CC(C)CCC1(C)CCC2C3CC=C4CC(O)CCC4C3CCC21C</smiles>

C

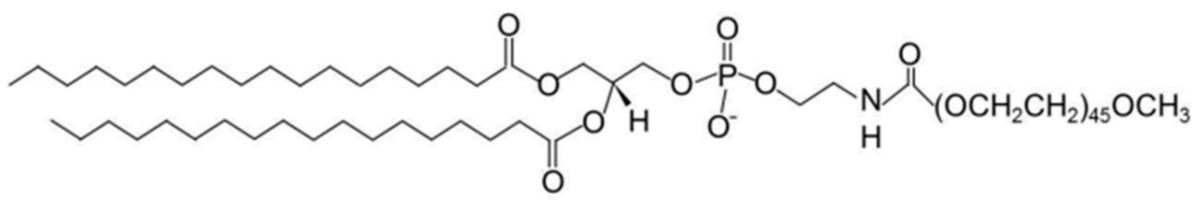

Figure 6. Structures of common liposomal constituents: (a) 1,2-distearoyl-sn-glycerophosphocholine (DSPC); (b) cholesterol; (c) 1,2-distearoyl-sn-glycero-3-phosphoethanolamine polyethylene glycol (DSPEPEG) [157]. 


\subsection{Polymer Micelles}

Polymer micelles are promising carriers for various kinds of drugs in medical application, thereby improving the efficacy of drugs and reducing side effects [164-169] (Figure 7). Micelles are usually formed by self-assembly of block polymers, which could be conjugated with different units such as polyethylene glycol and poly(amino acid) [169]. During the self-assembly of the polymers of micelles, therapeutic drugs such as DNA, RNA, proteins, and small molecular drugs with an abundant of functions could be encapsulated within the micelles [170-174].

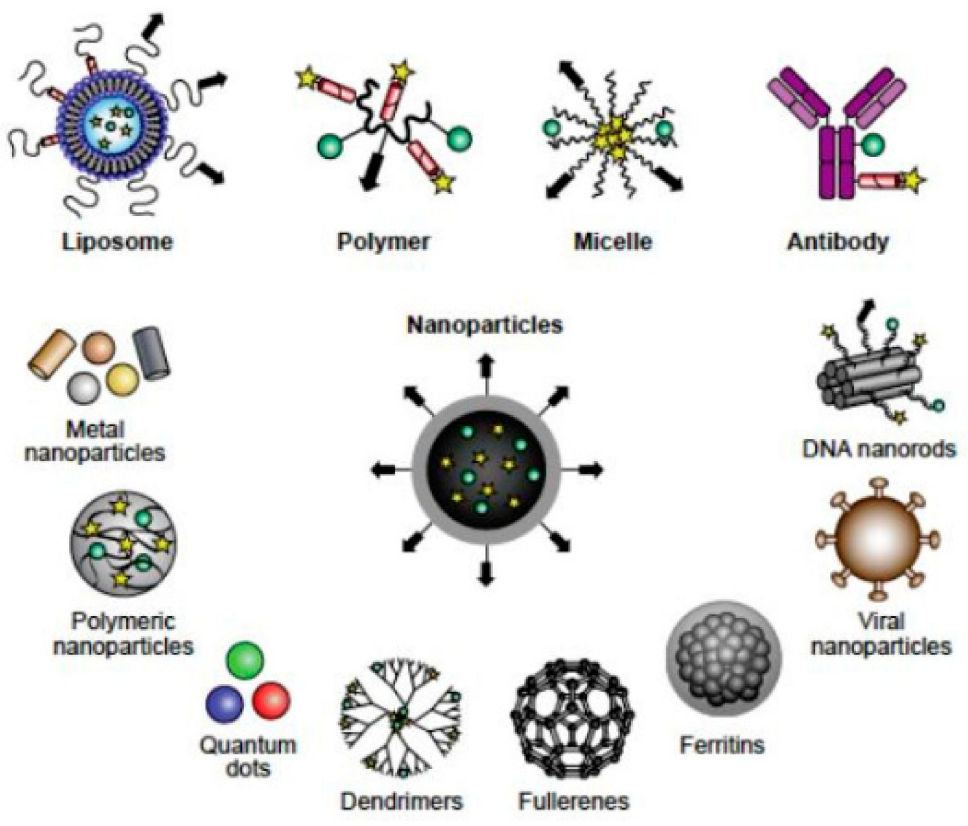

Figure 7. Biocompatible nanocarriers include those composed of liposomes, polymers, micelles, antibodies, nanoparticles composed of metals, and other biological molecules or combinations [167].

Although polymer micelles have good stability in vivo, drugs released from the micelles usually in a very slow diffusion mode, which lead to a low concentration of free drugs in tumor cells and would suppress the therapeutic outcome. It is necessary to design polymer micelles to release drugs with desirable dynamic behavior in tumor sites. $\mathrm{pH}$-responsive polymer micelles equipped with acidic trigger sections present an efficient drug delivery for cancer therapy [56], derived from the passive or active targeting potency and subsequent responsive release of payloads.

The design strategies of $\mathrm{pH}$-sensitive polymer micelles mainly include:

1. Protonated groups are introduced into the polymer chain through the mechanism of protonation/deprotonation [175-179]. The common functional groups of protonation include the amine group, imidazolyl group, sulfonic acid group, and carboxyl group. When such polymer micelles reach acidic target sites, rapid targeted release of the drug contained in the micelles would be triggered as the unstable micelle structures due to acidic precipitation/aggregation, or depolymerization.

2. $\mathrm{pH}$-sensitive chemical bonding arms are introduced between polymer chain segments or between polymers and drugs [180-182]. The acid sensitive connector arm refers to a molecule or group that can exist stably under neutral conditions but can hydrolyze quickly under weak acidic conditions, including imine bond [183], hydrazine bond, hydrazone bond [56,184-186], cisaconitamide, dimethyl maleamide [94,187], ether bond [56,188], orthate ester [70,188,189], polyacylaldehyde (ketone) [190], etc.

Pun et al. recently developed $\mathrm{pH}$-sensitive polymer micelles fabricated with self-assembly of lytic peptide modified diblock copolymers (PPCs). They demonstrated that significantly enhanced in vitro 
and in vivo transfection efficiency with melittin-like peptide polymer conjugate encapsulated in the micelles [191], indicating further in vivo gene therapy mediated by the peptide encapsulated micelles.

The surface modification of micelles, such as PEGylation, is important for their function [56]. The long chain of PEG may affect the uptake of micelles by cells for subsequent biological effects. Other modification strategies could be considered for improved uptake by cells, as a tactic folate acid and its variants can be used to modify the surface of micelles for improving cellular uptake, as folic acid receptors are usually highly expressed on many types of cancer cells. Xiong et al. successfully designed folate-conjugated crosslinked biodegradable micelles with poly(ethylene glycol)-b-poly(acryloyl carbonate)-b-poly(D,L-lactide) (PEG-PAC-PLA) and folate-PEG-PLA (FA-PEG-PLA) block copolymers for receptor-mediated delivery of paclitaxel (PTX) into KB cells for cancer therapy [192](Figure 8).

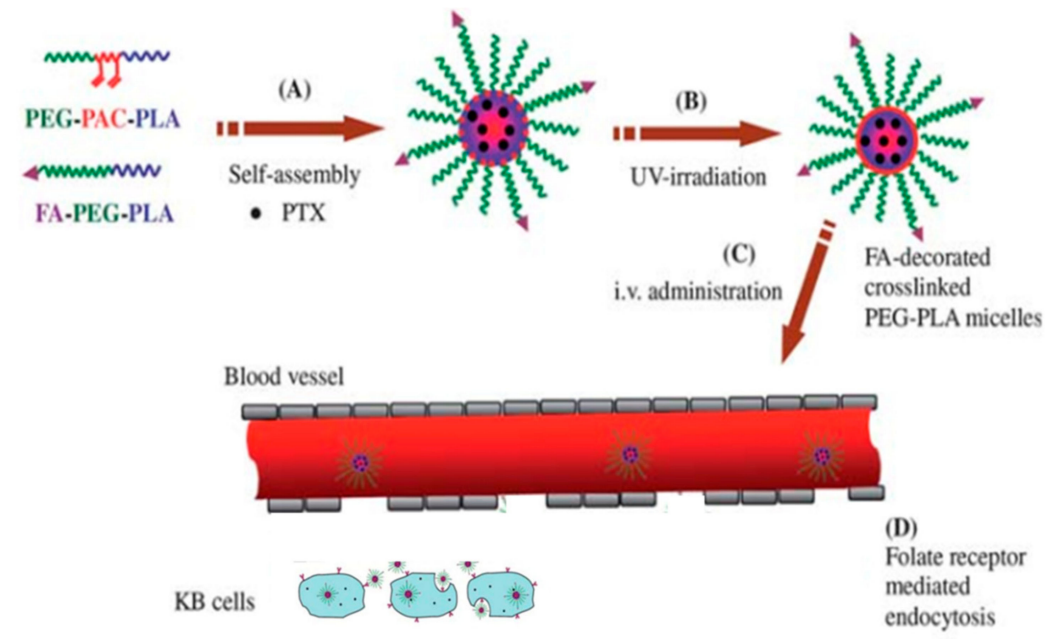

Figure 8. Illustration of folate-conjugated interfacially crosslinked biodegradable micelles for targeted delivery of paclitaxel [192].

\section{Conclusions and Future Prospects}

Over the last few decades, engineering biomaterials have strived to improve the therapeutic outcome with reduced effects, and great progress has been made in the application in drug delivery systems for medical applications, especially for cancer therapy. Several biomaterials with $\mathrm{pH}$ sensitivity have shown great potential for constructing effective drug delivery systems. In this review, we present an overview for $\mathrm{pH}$-sensitive bonds and $\mathrm{pH}$-sensitive nanomaterials for drug delivery in the past two decades. $\mathrm{pH}$-sensitive biomaterials for drug delivery are a research hotspot in the fields of biochemistry and medicine, and great progress has also been made in recent years. At the same time, most of the research is still in the experimental stage, and there are still many problems that need to be solved for translational application, such as the biocompatibility of some $\mathrm{pH}$-sensitive biomaterials, mass production with controllable quality, and potential toxicology of the carriers. Using $\mathrm{pH}$-sensitive chemical bonds to design and prepare $\mathrm{pH}$-sensitive biomedical materials based on acidic microenvironments of diseases would greatly improve the biocompatibilities and reduce potential toxicity of biomaterials. Microfluidics to screen the uniform size of biomaterials would greatly improve the consistency of synthesized samples with different batches.

Author Contributions: Conceptualization, S.Z.; F.Z., and J.Y.; writing-Original draft preparation, S.Z.; F.Z., J.Y. and X.Z.; supervision, X.Z., G.Y. and X.L.; project administration, X.L. All authors have read and agreed to the published version of the manuscript.

Funding: This work was supported by the startup funding from Jinan University, the Fundamental Research Funds for the Central Universities (No. 11618337), and the National Natural Science Foundation of China (No. 81903546).

Conflicts of Interest: The authors declare no conflict of interest. 


\section{References}

1. Fenton, O.S.; Katy, N.O.; Pillai, P.S.; Mitchell, M.J.; Langer, R. Advances in Biomaterials for Drug Delivery. Adv. Mater. 2018, 30, 1705328. [CrossRef]

2. Allen, T.M. Drug Delivery Systems: Entering the Mainstream. Science 2004, 303, 1818-1822. [CrossRef] [PubMed]

3. Tibbitt, M.W.; Dahlman, J.E.; Langer, R. Emerging Frontiers in Drug Delivery. J. Am. Chem. Soc. 2016, 138, 704-717. [CrossRef] [PubMed]

4. Huebsch, N.; Mooney, D.J. Inspiration and application in the evolution of biomaterials. Nature 2009, 462, 426-432.

5. Lu, Y.A.; Alex, A.; Langer, R.; Gu, Z. Bioresponsive materials. Nat. Rev. Mater. 2016, 1, 16075. [CrossRef]

6. Yun, H.Y.; Lee, B.K.; Park, K. Controlled Drug Delivery: Historical perspective for the next generation. J. Control. Release 2015, 219, 2-7. [CrossRef]

7. Kanamala, M.R.; Wilson, W.; Yang, M.; Palmer, B.D.; Wu, Z. Mechanisms and biomaterials in pH-responsive tumour targeted drug delivery: A review. Biomaterials 2016, 85, 152-167. [CrossRef]

8. Liu, J.; Huang, Y.; Kumar, A.; Tan, A.; Jin, S.; Mozhi, A.; Liang, X. pH-Sensitive nano-systems for drug delivery in cancer therapy. Biotechnol. Adv. 2014, 32, 693-710. [CrossRef]

9. Cao, Y.; Ronald, A.D.; Matthias, E.; Vousden, K. Cancer research: Past, present and future. Nat. Rev. Cancer 2011, 11, 749-754. [CrossRef]

10. Patel, N.R.P.; Bhushan, S.; Abouzeid, H.A.; Torchilin, P.V. Nanopreparations to overcome multidrug resistance in cancer. Adv. Drug Deliv. Rev. 2013, 65, 1748-1762. [CrossRef]

11. Shen, M.; Huang, Y.-Z.; Han, L.; Qin, J.; Fang, X.; Wang, J.; Yang, V.C. Multifunctional drug delivery system for targeting tumor and its acidic microenvironment. J. Control. Release 2012, 161, 884-892. [CrossRef] [PubMed]

12. Danhier, F.; Feron, O.; Préat, V. To exploit the tumor microenvironment: Passive and active tumor targeting of nanocarriers for anti-cancer drug delivery. J. Control. Release 2010, 148, 135-146. [CrossRef]

13. Trédan, O.; Galmarini, C.M.; Patel, K.; Tannock, I.F. Drug resistance and the solid tumor microenvironment. J. Natl. Cancer I. 2007, 99, 1441-1454. [CrossRef] [PubMed]

14. Whiteside, T.L. The tumor microenvironment and its role in promoting tumor growth. Oncogene 2008, 27, 5904-5912. [CrossRef] [PubMed]

15. Brown, J.M.; Wilson, W.R. Exploiting tumour hypoxia in cancer treatment. Nat. Rev. Cancer 2004, 4, 437-447. [CrossRef] [PubMed]

16. Lou, Y.; McDonald, P.C.; Oloumi, A.; Chia, S.; Ostlund, C.; Ahmadi, A.; Kyle, A.; Keller, U.A.D.; Leung, S.; Huntsman, D.; et al. Targeting tumor hypoxia: Suppression of breast tumor growth and metastasis by novel carbonic anhydrase IX inhibitors. Cancer Res. 2011, 71, 3364-3376. [CrossRef]

17. Milosevic, M.; Warde, P.; Menard, C.; Chung, P.; Toi, A.; Ishkanian, A.; McLean, M.; Pintilie, M.; Sykes, J.; Gospodarowicz, M.; et al. Tumor hypoxia predicts biochemical failure following radiotherapy for clinically localized prostate cancer. Clin. Cancer Res. 2012, 18, 2108-2114. [CrossRef]

18. Estrella, V.; Chen, T.; Lloyd, M.; Wojtkowiak, J.; Cornnell, H.H.; Ibrahim-Hashim, A.; Bailey, K.; Balagurunathan, Y.; Rothberg, J.M.; Sloane, B.F.; et al. Acidity Generated by the Tumor Microenvironment Drives Local Invasion. Cancer Res. 2013, 73, 1524-1535. [CrossRef]

19. Ji, R.-C. Hypoxia and lymphangiogenesis in tumor microenvironment and metastasis. Cancer Lett. 2014, 346, 6-16. [CrossRef]

20. Fukumura, D.; Duda, D.G.; Munn, L.L.; Jain, R.K. Tumor Microvasculature and Microenvironment: Novel Insights Through Intravital Imaging in Pre-Clinical Models. Microcirculation 2010, 17, $206-225$. [CrossRef]

21. Liu, X.; Zhang, P.; He, D.; Rödl, W.; Preiß, T.; Rädler, J.O.; Wagner, E.; Lächelt, U. pH-Reversible Cationic RNase A Conjugates for Enhanced Cellular Delivery and Tumor Cell Killing. Biomacromolecules 2016, 17, 173-182. [CrossRef] [PubMed]

22. Jhaveri, A.; Pranali, D.; Torchilin, V. Stimuli-sensitive nanopreparations for combination cancer therapy. J. Control. Release 2014, 190, 352-370. [CrossRef] [PubMed]

23. Pathania, D.; Millard, M.; Neamati, N. Opportunities in discovery and delivery of anticancer drugs targeting mitochondria and cancer cell metabolism. Adv. Drug Deliv. Rev. 2009, 61, 1250-1275. [CrossRef] [PubMed] 
24. Wicki, A.; Dominik, W.; Balasubramanian, V.; Huwyler, J. Nanomedicine in cancer therapy: Challenges, opportunities, and clinical applications. J. Control. Release 2015, 200, 138-157. [CrossRef]

25. Ulrich, S. Growing Prospects of Dynamic Covalent Chemistry in Delivery Applications. Acc. Chem. Res. 2019, 52, 510-519. [CrossRef]

26. Leriche, G.; Chisholm, L.; Wagner, A. Cleavable linkers in chemical biology. Bioorganic Med. Chem. 2012, 20, 571-582. [CrossRef]

27. Bernardes, G.J.; Boutureira, O.L. Advances in Chemical Protein Modification. Chem. Rev. 2015, 115, $2174-2195$.

28. Herrmann, A. Dynamic combinatorial/covalent chemistry: A tool to read, generate and modulate the bioactivity of compounds and compound mixtures. Chem. Soc. Rev. 2014, 43, 1899-1933. [CrossRef]

29. West, K.; Sijbren, O. Reversible Covalent Chemistry in Drug Delivery. Curr. Drug Discov. Technol. 2005, 2, $123-160$. [CrossRef]

30. Webber, M.J.; Robert, L. Drug delivery by supramolecular design. Chem. Soc. Rev. 2017, 46, 6600-6620. [CrossRef]

31. Wells, C.M.; Harris, M.; Choi, L.; Murali, V.P.; Guerra, F.D.; Jennings, J.A. Stimuli-Responsive Drug Release from Smart Polymers. J. Funct. Biomater. 2019, 10, 34. [CrossRef]

32. Drozdz, W.; Camille, B.; Kotras, C.; Richeter, S.; Barboiu, M.; Clement, S.; Stefankiewicz, A.R.; Ulrich, S. Generation of Multicomponent Molecular Cages using Simultaneous Dynamic Covalent Reactions. Chem. A Eur. J. 2017, 23, 18010-18018. [CrossRef] [PubMed]

33. Pacifici, N.; Bolandparvaz, A.; Lewis, J.S. Stimuli-esponsive Biomaterials for Vaccines and Immunotherapeutic Applications. Adv. Ther. 2020, 3, 2000129. [CrossRef] [PubMed]

34. Jain, K.N.; Tare, S.M.; Mishra, V.; Tripathi, K.P. The development, characterization and in vivo anti-ovarian cancer activity of poly(propylene imine) (PPI)-antibody conjugates containing encapsulated paclitaxel. Nanomed. Nanotechnol. Biol. Med. 2015, 11, 207-218. [CrossRef] [PubMed]

35. Lemieux, G. Chemoselective ligation reactions with proteins, oligosaccharides and cells. Trends Biotechnol. 1998, 16, 506-513. [CrossRef]

36. Zeng, X.; Gan, L.; Tao, W.; Ma, Y.; Zhang, X.; He, F.; Pan, J.; Mei, L.; Pan, G. A Drug-Self-Gated Mesoporous Antitumor Nanoplatform Based on pH-Sensitive Dynamic Covalent Bond. Adv. Funct. Mater. 2017, $27,27$. [CrossRef]

37. Cheng, C.; Yabin, M.; Zhang, Z.; Chen, J.; Zhang, Q. Imine Bond- and Coordinate Bond-Linked pH-Sensitive Cisplatin Complex Nanoparticles for Active Targeting to Tumor Cells. J. Nanosci. Nanotechnol. 2019, 19, 3277-3287. [CrossRef] [PubMed]

38. Zhu, L.; Zhao, L.; Qu, X.; Yang, Z. pH-Sensitive Polymeric Vesicles from Coassembly of Amphiphilic Cholate Grafted Poly(L-lysine) and Acid-Cleavable Polymer-Drug Conjugate. Langmuir Acs J. Surf. Colloids 2012, 28, 11988-11996. [CrossRef]

39. Chen, H.; Chen, Z.; Kuang, Y.; Li, S.; Zhang, M.; Liu, J.; Sun, Z.; Jiang, B.; Chen, X.; Li, C. Stepwise-acid-active organic/inorganic hybrid drug delivery system for cancer therapy. Colloids Surf. B Biointerfaces 2018, 167, 407-414. [CrossRef]

40. Gu, J.; Cheng, W.-P.; Liu, J.; Lo, S.-Y.; Smith, D.; Qu, X.; Yang, Z. pH-Triggered Reversible "stealth"Polycationic Micelles. Biomacromolecules 2008, 9, 255-262. [CrossRef]

41. Suri, S.S.; Fenniri, H.; Singh, B. Nanotechnology-based Drug Delivery Systems. J. Occup. Med. Toxicol. 2007. [CrossRef] [PubMed]

42. Tao, Y.; Liu, S.; Zhang, Y.; Chi, Z.; Xu, J. A pH-responsive polymer based on dynamic imine bonds as a drug delivery material with pseudo target release behavior. Polym. Chem. 2018, 9, 878-884. [CrossRef]

43. Xu, J.; Benkai, Q.; Luan, S.; Qi, P.; Wang, Y.; Wang, K.; Song, S. Acid-labile poly(ethylene glycol) shell of hydrazone-containing biodegradable polymeric micelles facilitating anticancer drug delivery. J. Bioact. Compat. Polym. 2018, 33, 119-133. [CrossRef]

44. Liang, Y.; Zhihui, S.; Yao, Y.; Zhang, N. Preparation of pH Sensitive Pluronic-Docetaxel Conjugate Micelles to Balance the Stability and Controlled Release Issues. Materials 2015, 8, 379-391. [CrossRef] [PubMed]

45. Rahoui, N.; Bo, J.; Taloub, N.; Hegazy, M.; Huang, Y.D. Synthesis and evaluation of water soluble $\mathrm{pH}$ sensitive poly (vinyl alcohol)-doxorubicin conjugates. J. Biomater. Sci. Polym. Ed. 2018, 29, 1482-1497. [CrossRef]

46. Su, Z.; Liang, Y.; Yao, Y.; Wang, T.; Zhang, N. Polymeric complex micelles based on the double-hydrazone linkage and dual drug-loading strategy for $\mathrm{pH}$-sensitive docetaxel delivery. J. Mater. Chem. B 2016, 4, 1122-1133. [CrossRef] 
47. Wang, L.; Ren, K.-F.; Wang, H.-B.; Wang, Y.; Ji, J. pH-sensitive controlled release of doxorubicin from polyelectrolyte multilayers. Colloids Surfaces B Biointerfaces 2015, 125, 127-133. [CrossRef]

48. Sun, T.-M.; Wang, Y.-C.; Wang, F.; Du, J.-Z.; Mao, C.-Q.; Sun, C.-Y.; Tang, R.-Z.; Zhu, Y.; Zhu, Y.-H.; Yang, X.-Z.; et al. Cancer stem cell therapy using doxorubicin conjugated to gold nanoparticles via hydrazone bonds. Biomaterials 2014, 35, 836-845. [CrossRef]

49. Jiang, T.; You-Mei, L.; Lv, Y.; Cheng, Y.; He, F.; Zhuo, R. Amphiphilic polycarbonate conjugates of doxorubicin with pH-sensitive hydrazone linker for controlled release. Colloids Surf. B Biointerfaces 2013, 111, 542-548. [CrossRef]

50. Sirova, M.; Mrkvan, T.; Etrych, T.; Chytil, P.; Rossmann, P.; Ibrahimova, M.; Kovář, L.; Ulbrich, K.; Říhová, B. Preclinical Evaluation of Linear HPMA-Doxorubicin Conjugates with pH-Sensitive Drug Release: Efficacy, Safety, and Immunomodulating Activity in Murine Model. Pharm. Res. 2009, 27, 200. [CrossRef]

51. Qi, P.; Wu, X.; Liu, L.; Yu, H.; Song, S. Hydrazone-Containing Triblock Copolymeric Micelles for pH-Controlled Drug Delivery. Front. Pharmacol. 2018, 9, 12. [CrossRef] [PubMed]

52. Szabó, I.; Manea, M.; Orbán, E.; Csámpai, A.; Bosze, S.; Szabó, R.; Tejeda, M.; Gaál, D.; Kapuvári, B.; Przybylski, M.; et al. Development of an Oxime Bond Containing Daunorubicin-Gonadotropin-Releasing Hormone-III Conjugate as a Potential Anticancer Drug. Bioconjug. Chem. 2009, 20, 656-665. [CrossRef] [PubMed]

53. Jin, Y.; Song, L.; Su, Y.; Zhu, L.; Pang, Y.; Qiu, F.; Tong, G.; Yan, D.; Zhu, B.; Zhu, X. Oxime lnkage: A robust tool for the design of $\mathrm{pH}$-sensitive polymeric drug carriers. Biomacromolecules 2011, 12, 3460-3468. [CrossRef] [PubMed]

54. Kölmel, D.K.; Kool, E.T. Oximes and Hydrazones in Bioconjugation: Mechanism and Catalysis. Chem. Rev. 2017, 117, 10358-10376. [CrossRef] [PubMed]

55. Liu, B.; Chen, H.; Li, X.; Zhao, C.; Liu, Y.; Zhu, L.; Deng, H.; Li, J.; Li, G.; Guo, F.; et al. pH-responsive flower-like micelles constructed via oxime linkage for anticancer drug delivery. Rsc Adv. 2014, 4, 48943-48951. [CrossRef]

56. Deng, H.; Liu, J.; Zhao, X.; Zhang, Y.; Liu, J.; Xu, S.; Deng, L.; Dong, A.; Zhang, J. PEG-b-PCL CopolymerMicelles with the Ability of $\mathrm{pH}$-Controlled Negative-to-Positive ChargeReversal for Intracellular Delivery of Doxorubicin. Biomacromolecules 2014, 15, 4281-4292. [CrossRef] [PubMed]

57. Zloh, M.; Dinand, E.; Brocchini, S. Aconityl-derived polymers for biomedical applications. Modeling study of cis-trans isomerisation. Theor. Chem. Acc. 2003, 109, 206-212. [CrossRef]

58. Liu, G.-Y.; Li, M.; Zhu, C.-S.; Jin, Q.; Zhang, Z.; Ji, J. Charge-conversional and pH-sensitive PEGylated polymeric micelles as efficient nanocarriers for drug delivery. Macromol. Bioence 2015, 14, 1280-1290. [CrossRef]

59. Chen, J.; Ding, J.; Zhang, Y.; Xiao, C.; Zhuang, X.; Chen, X. Polyion complex micelles with gradient $\mathrm{pH}$-sensitivity for adjustable intracellular drug delivery. Polym. Chem. 2014, 6, 397-405. [CrossRef]

60. Shao, W.; Liu, C.; Ma, H.; Hong, Z.; Xie, Q.; Lu, Y. Fabrication of pH-sensitive thin-film nanocomposite nanofiltration membranes with enhanced performance by incorporating amine-functionalized graphene oxide. Appl. Surface Sci. 2019, 487, 1209-1221. [CrossRef]

61. Banks, S.R.; Enck, K.; Wright, M.; Opara, E.C.; Welker, M.E. Chemical Modification of Alginate for Controlled Oral Drug Delivery. J. Agric. Food Chem. 2019, 67, 10481-10488. [CrossRef] [PubMed]

62. Fu, L.; Sun, C.; Yan, L. Galactose Targeted pH-Responsive Copolymer Conjugated with Near Infrared Fluorescence Probe for Imaging of Intelligent Drug Delivery. ACS Appl. Mater. Interfaces 2015, 7, 2104-2115. [CrossRef] [PubMed]

63. Cao, J.; Su, T.; Zhang, L.; Liu, R.; Wang, G.; He, B.; Gu, Z. Polymeric micelles with citraconic amide as pH-sensitive bond in backbone for anticancer drug delivery. Int. J. Pharm. 2014, 471, 28-36. [CrossRef] [PubMed]

64. Cai, S.; Thati, S.; Bagby, T.R.; Diab, H.-M.; Davies, N.M.; Cohen, M.S.; Forrest, M.L. Localized doxorubicin chemotherapy with a biopolymeric nanocarrier improves survival and reduces toxicity in xenografts of human breast cancer. J. Control. Release 2010, 146, 212-218. [CrossRef] [PubMed]

65. Zhai, Y.; Zhou, X.; Jia, L.; Ma, C.; Song, R.; Deng, Y.; Hu, X.; Sun, W. Acetal-Linked Paclitaxel Polymeric Prodrug Based on Functionalized mPEG-PCL Diblock Polymer for $\mathrm{pH}$-Triggered Drug Delivery. Polymers 2017, 9, 698. [CrossRef] [PubMed]

66. Dimde, M.; Steinhilber, D.; Neumann, F.; Li, Y.; Paulus, F.; Ma, N.; Haag, R. Synthesis of pH-Cleavable dPG-Amines for Gene Delivery Application. Macromol. Biosci. 2017, 17, 1600190. [CrossRef] 
67. Gillies, E.R.; Goodwin, A.P.; Fréchet, J.M.J. Acetals as pH-sensitive linkages for drug delivery. Bioconjug. Chem. 2004, 15, 1254-1263. [CrossRef]

68. Huang, F.; Cheng, R.; Meng, F.; Deng, C.; Zhong, Z. Micelles Based on Acid Degradable Poly(acetal urethane): Preparation, pH-Sensitivity, and Triggered Intracellular Drug Release. Biomacromolecules 2015, 16, 2228-2236. [CrossRef]

69. Li, J.; Zhang, X.; Zhao, M.; Wu, L.; Luo, K.; Pu, Y.; He, B. Tumor-pH-Sensitive PLLA-Based Microsphere with Acid Cleavable Acetal Bonds on the Backbone for Efficient Localized Chemotherapy. Biomacromolecules 2018, 19, 3140-3148. [CrossRef]

70. Masson, C.; Garinot, M.; Mignet, N.; Wetzer, B.; Mailhe, P.; Scherman, D.; Bessodes, M. pH-sensitive PEG lipids containing orthoester linkers: New potential tools for nonviral gene delivery. J Control Release 2004, 99, 423-434. [CrossRef]

71. Thambi, T.; Deepagan, V.; Yoo, C.K.; Park, J.H. Synthesis and physicochemical characterization of amphiphilic block copolymers bearing acid-sensitive orthoester linkage as the drug carrier. Polymer 2011, 52, 4753-4759. [CrossRef]

72. Du, H.; Liu, M.; Yang, X.; Zhai, G. The design of pH-sensitive chitosan-based formulations for gastrointestinal delivery. Drug Discov. Today 2015, 20, 1004-1011. [CrossRef]

73. Xin-long, Z.; Xiu-feng, Z.; Da-wei, C.; Xiu-li, Z. Recent progress of design targeted vector pH responsive to tumor microenvironment. J. Shenyang Pharm. Univ. 2014, 31, 575-583.

74. Siddique, S.; Chow, J.C.L. Application of Nanomaterials in Biomedical Imaging and Cancer Therapy. Nanomaterials 2020, 10, 1700. [CrossRef] [PubMed]

75. Fleige, E.; Quadir, M.A.; Haag, R. Stimuli-responsive polymeric nanocarriers for the controlled transport of active compounds: Concepts and applications. Adv. Drug Deliv. Rev. 2012, 64, 866-884. [CrossRef] [PubMed]

76. Liu, Y.; Wang, W.; Yang, J.; Zhou, C.; Sun, J. pH-sensitive polymeric micelles triggered drug release for extracellular and intracellular drug targeting delivery. Asian J. Pharm. Sci. 2013, 8, 159-167. [CrossRef]

77. Torchilin, V.P. Nanotechnology for Intracellular Delivery and Targeting. Nanotechnol. Drug Deliv. 2009, 313-346. [CrossRef]

78. Baliga, S.; Muglikar, S.; Kale, R. Salivary pH: A Diagnostic Biomarker. J. Indian Soc. Periodontol. 2013, 17, 461-465. [CrossRef]

79. Yin, Q.; Shen, J.; Zhang, Z.; Yu, H.; Li, Y. Reversal of multidrug resistance by stimuli-responsive drug delivery systems for therapy of tumor. Adv. Drug Deliv. Rev. 2013, 65, 1699-1715. [CrossRef]

80. Yasuhiro, M. The Drug Discovery by NanoMedicine and its Clinical Experience. Jpn. J. Clin. Oncol. 2014, 44, 515-525.

81. Mura, S.; Nicolas, J.; Couvreur, P. Stimuli-responsive nanocarriers for drug delivery. Nat. Mater. 2013, 12, 991-1003. [CrossRef] [PubMed]

82. Du, J.; Lane, L.A.; Nie, S. Stimuli-responsive nanoparticles for targeting the tumor microenvironment. J. Control. Release 2015, 219, 205-214. [CrossRef] [PubMed]

83. Siddique, S.; Chow, J.C.L. Gold Nanoparticles for Drug Delivery and Cancer Therapy. Appl. Sci. 2020, 10, 3824.

84. Ganta, S.; Devalapally, H.; Shahiwala, A.; Amiji, M. A review of stimuli-responsive nanocarriers for drug and gene delivery. J. Control. Release 2008, 126, 187-204. [CrossRef] [PubMed]

85. Sharma, R.; Mody, N.; Agrawal, U.; Vyas, S.P.; Sharma, R. Theranostic Nanomedicine; A Next Generation Platform for Cancer Diagnosis and Therapy. Mini Reviews Med. Chem. 2017, 17, 1746-1757. [CrossRef] [PubMed]

86. Manivasagan, P.; Bharathiraja, S.; Moorthy, M.S.; Oh, Y.-O.; Seo, H.; Oh, J. Marine Biopolymer-Based Nanomaterials as a Novel Platform for Theranostic Applications. Polym. Rev. 2017, 57, 631-667. [CrossRef]

87. Popović, Z.; Liu, W.; Chauhan, V.P.; Lee, J.; Wong, C.; Greytak, A.B.; Insin, N.; Nocera, D.G.; Fukumura, D.; Jain, R.K.; et al. A nanoparticle size series for in vivo fluorescence imaging. Angew. Chem. 2010, 122, 8831-8834. [CrossRef]

88. Liu, S.; Wang, L.; Zhang, M.; Tao, K.; Wang, B.; Lin, M.; Zhang, X.; Liu, Y.; Hou, Y.; Zhang, H.; et al. Tumor Microenvironment-Responsive Nanoshuttles with Sodium Citrate Modification for Hierarchical Targeting and Improved Tumor Theranostics. ACS Appl. Mater. Interfaces 2019, 11, 25730-25739. [CrossRef]

89. Chan, C.-F.; Zhou, Y.; Guo, H.; Zhang, J.; Jiang, L.; Chen, W.; Shiu, K.-K.; Kwong, D.W.J.; Wong, K.-L. pH-Dependent Cancer-Directed Photodynamic Therapy by a Water-Soluble Graphitic-Phase Carbon Nitride-Porphyrin Nanoprobe. ChemPlusChem 2016, 81, 535-540. [CrossRef] 
90. Pourjavadi, A.; Kohestanian, M.; Shirzad, M. Synthesis and characterization of magnetic hybrid nanomaterials via RAFT polymerization: A pH sensitive drug delivery system. Colloids Surf. B Biointerfaces 2019, 174, 153-160. [CrossRef]

91. He, H.; Chen, S.; Zhou, J.; Dou, Y.; Song, L.; Che, L.; Zhou, X.; Chen, X.; Jia, Y.; Zhang, J.; et al. Cyclodextrin-derived pH-responsive nanoparticles for delivery of paclitaxel. Biomaterials 2013, 34, 5344-5358. [CrossRef] [PubMed]

92. Shi, Z.; Li, Q.; Mei, L. pH-Sensitive nanoscale materials as robust drug delivery systems for cancer therapy. Chin. Chem. Lett. 2020, 31, 1345-1356. [CrossRef]

93. Chen, H.; Zheng, D.; Liu, J.; Kuang, Y.; Li, Q.; Zhang, M.; Ye, H.; Qin, H.; Xu, Y.; Li, C.; et al. pH-Sensitive drug delivery system based on modified dextrin coated mesoporous silica nanoparticles. Int. J. Biol. Macromol. 2016, 85, 596-603. [CrossRef] [PubMed]

94. Ding, J.-X.; Li, D.; Zhuang, X.; Chen, X. Self-assemblies of pH-activatable PEGylated multiarm poly(lactic acid-co-glycolic acid)-doxorubicin prodrugs with improved long-term antitumor efficacies. Macromol. Biosci. 2013, 13, 1300-1307. [CrossRef]

95. YYar, M.; Shahzad, S.; Siddiqi, S.A.; Mahmood, N.; Rauf, A.; Anwar, M.S.; Chaudhry, A.A.; Rehman, I.U. Triethyl orthoformate mediated a novel crosslinking method for the preparation of hydrogels for tissue engineering applications: Characterization and in vitro cytocompatibility analysis. Mater. Sci. Eng. C 2015, 56, 154-164. [CrossRef]

96. Samanta, H.S.; Ray, S.K. Controlled Release of Tinidazole and Theophylline from Chitosan Based Composite Hydrogels. Carbohydr. Polym. 2014, 106, 109-120. [CrossRef]

97. Hoare, T.R.; Kohane, D.S. Hydrogels in drug delivery: Progress and challenges. Polymer 2008, 49, $1993-2007$. [CrossRef]

98. Hendi, A.; Hassan, M.U.; Elsherif, M.; Alqattan, B.; Park, S.; Yetisen, A.K.; Butt, H. Healthcare Applications of pH-Sensitive Hydrogel-Based Devices: A Review. Int. J. Nanomed. 2020, 15, 3887-3901. [CrossRef]

99. Ana, H.B.; Ibrahim, F.C.; Joana, S.-C.; Rui, A.S.; Joaquim, M.O.; Rui, L.R. "Smart” Hydrogels in Tissue Engineering and Regenerative Medicine Applications. Handb. Intell. Scaffolds Regen. 2017, 333-367.

100. Zhao, Y.; Lei, M.; Liu, S.-X.; Zhao, Q. Smart hydrogel-based optical fiber SPR sensor for $\mathrm{pH}$ measurements. Sens. Actuators B Chem. 2018, 261, 226-232. [CrossRef]

101. Wichterle, O.; Lím, D. Hydrophilic Gels for Biological Use. Nature 1960, 185, 117-118. [CrossRef]

102. Moreddu, R.; Elsherif, M.; Butt, H.; Vigolo, D.; Yetisen, A.K. Contact lenses for continuous corneal temperature monitoring. RSC Adv. 2019, 9, 11433-11442. [CrossRef]

103. Hunt, J.; Chen, R.; Van Veen, T.; Bryan, N. Hydrogels for tissue engineering and regenerative medicine. J. Mater. Chem. B 2014, 2, 5319-5338. [CrossRef] [PubMed]

104. Elsherif, M.; Hassan, M.U.; Yetisen, A.K.; Butt, H. Hydrogel optical fibers for continuous glucose monitoring. Biosens. Bioelectron. 2019, 137, 125-132. [CrossRef] [PubMed]

105. Etrych, T.; Jelínková, M.; Ř́nhová, B.; Ulbrich, K. New HPMA copolymers containing doxorubicin bound via $\mathrm{pH}$-sensitive linkage: Synthesis and preliminary in vitro and in vivo biological properties. J. Control. Release 2001, 73, 89-102. [CrossRef]

106. Vashist, A.; Kaushik, A.; Alexis, K.; Jayant, R.D.; Sagar, V.; Vashist, A.; Nair, M. Bioresponsive Injectable Hydrogels for On-demand Drug Release and Tissue Engineering. Curr. Pharm. Des. 2017, 23, 3595-3602. [CrossRef]

107. Onaciu, A.; Munteanu, R.A.; Moldovan, C.S.; Berindan-Neagoe, I. Hydrogels Based Drug Delivery Synthesis, Characterization and Administration. Pharmaceutics 2019, 11, 432. [CrossRef]

108. Li, X.; Su, X. Multifunctional smart hydrogels: Potential in tissue engineering and cancer therapy. J. Mater. Chem. B Mater. Biol. 2018, 6, 4714-4730. [CrossRef]

109. Vemula, P.K.; Wiradharma, N.; Ankrum, J.A.; Miranda, O.R.; John, G.; Karp, J.M. Prodrugs as self-assembled hydrogels: A new paradigm for biomaterials. Curr. Opin. Biotechnol. 2013, 24, 1174-1182. [CrossRef]

110. Wang, Y.; Cheetham, A.G.; Angacian, G.; Su, H.; Xie, L.; Cui, H. Peptide-drug conjugates as effective prodrug strategies for targeted delivery. Adv. Drug Deliv. Rev. 2017, 110, 112-126. [CrossRef]

111. Oliva, N.; Conde, J.; Wang, K.; Artzi, N. Designing Hydrogels for On-Demand Therapy. Acc. Chem. Res. 2017, 50, 669-679. [CrossRef] [PubMed]

112. Tomar, L.K.; Tyagi, C.; Choonara, Y.E.; Kumar, P.; Pillay, V. Rheological and Swelling Behavior of pH Sensitive Hydrogel Particles. APCBEE Procedia 2014, 9, 192-196. [CrossRef] 
113. Yadav, H.K.S.; Shivakumar, H.G. In Vitro and In Vivo Evaluation of pH-Sensitive Hydrogels of Carboxymethyl Chitosan for Intestinal Delivery of Theophylline. Isrn Pharm. 2012, 2012, 1-9.

114. Wu, R.-S.; Lin, J.; Xing, Y.-M.; Dai, Z.; Wang, L.-W.; Zhang, X.-P. PH-sensitive Black Phosphorous Incorporated Hydrogel as Novel Implant for Cancer Treatment. J. Pharm. Sci. 2019, 108, 2542-2551. [CrossRef]

115. Qi, X.; Wei, W.; Li, J.; Zuo, G.; Pan, X.; Su, T.; Zhang, J.; Dong, W. Salecan-Based pH-Sensitive Hydrogels for Insulin Delivery. Mol. Pharm. 2017, 14, 431-440. [CrossRef]

116. Qi, X.; Wei, W.; Li, J.; Zuo, G.; Pan, X.; Su, T.; Zhang, J.; Dong, W. Metabolic Study of Cancer Cells Using a pH Sensitive Hydrogel Nanofiber Light Addressable Potentiometric Sensor. ACS Sens. 2017, 2, 151-156.

117. Pal, K.; Singh, V.K.; Anis, A.; Thakur, G.; Bhattacharya, M.K. Hydrogel-Based Controlled Release Formulations: Designing Considerations, Characterization Techniques and Applications. J. Macromol. Sci. Part D 2013, 52, 1391-1422. [CrossRef]

118. Chitra, G.; Selvi, M.S.; Franklin, D.S.; Sudarsan, S.; Sakthivel, M.; Guhanathan, S. pH-sensitive biopolymeric hydrogel-based on indole-3-acetic acid for wound healing and anti-cancer applications. SN Appl. Ences 2019, 1, 1641. [CrossRef]

119. Shim, J.K.; Lee, Y.B.; Lee, Y.M. pH-Dependent permeation through polysulfone ultrafiltration membranes prepared by ultraviolet polymerization technique. J. Appl. Polym. Sci. 1999, 74, 75-82. [CrossRef]

120. Peng, T.; Cheng, Y.L. PNIPAAm and PMAA co-g rafted porous PE membranes:living radical co-grafting mechanism and multi-stimuli responsive permeability. Polymer 2001, 42, 2091-2100. [CrossRef]

121. Ullah, F.; Othman, M.B.H.; Javed, F.; Ahmad, Z.; Md. Akil, H. Classification, Processing and Application of Hydrogels: A Review. Mater. Sci. Eng. C 2015, 57, 414-433. [CrossRef] [PubMed]

122. Gupta, P.; Vermani, K.; Garg, S. Hydrogels: From Controlled Release to pH-Responsive Drug Delivery. Drug Discov. Today 2002, 7, 569-579. [CrossRef]

123. Mukhopadhyay, P.; Sarkar, K.; Bhattacharya, S.; Bhattacharyya, A.; Mishra, R.; Kundu, P.P. pH sensitive $\mathrm{N}$-succinyl chitosan grafted polyacrylamide hydrogel for oral insulin delivery. Carbohyd. Polym. 2014, 112, 627-637. [CrossRef] [PubMed]

124. Xu, Q.; Huang, W.; Jiang, L.; Lei, Z.; Li, X.; Deng, H. KGM and PMAA based pH-sensitive interpenetrating polymer network hydrogel for controlled drug release. Carbohydr. Polym. 2013, 97, 565-570. [CrossRef] [PubMed]

125. Na, K.; Lee, E.S.; Bae, Y.H. Self-Organized Nanogels Responding to Tumor Extracellular pH: pH-Dependent Drug Release and in Vitro Cytotoxicity against MCF-7 Cells. Bioconjug. Chem. 2007, 18, 1568-1574. [CrossRef] [PubMed]

126. Niu, Y.; Yuan, X.; Zhao, Y.; Zhang, W.; Ren, L. Temperature and pH Dual-Responsive Supramolecular Polymer Hydrogels Hybridized with Functional Inorganic Nanoparticles. Macromol. Chem. Phys. 2017, 218, 1600540. [CrossRef]

127. Way, A.E.; Hsu, L.; Shanmuganathan, K.; Weder, C.; Rowan, S.J. pH-Responsive Cellulose Nanocrystal Gels and Nanocomposites. ACS Macro Lett. 2012, 1, 1001-1006. [CrossRef]

128. Bangham, A.D.; Standish, M.M.; Weissmann, G. The action of steroids and streptolysin S on the permeability of phospholipid structures to cations. J. Mol. Biol. 1965, 13, 253-259. [CrossRef]

129. Sessa, G.; Weissmann, G. Phospholipid spherules (liposomes) as a model for biological membranes. J. Lipid Res. 1968, 9, 310-318.

130. Gabizon, A.; Papahadjooulos, D. Liposome formulations with prolonged circulation time in blood and enhanced uptake by tumors. Proc. Natl. Acad. Sci. USA 1988, 85, 6949-6953. [CrossRef]

131. Xing, H.; Hwang, K.; Lu, Y. Recent Developments of Liposomes as Nanocarriers for Theranostic Applications. Theranostics 2016, 6, 1336-1352. [CrossRef] [PubMed]

132. Abu Lila, A.S.; Ishida, T. Liposomal Delivery Systems: Design Optimization and Current Applications. Biol. Pharm. Bull. 2017, 40,1-10. [CrossRef] [PubMed]

133. Torchilin, V.P. Recent advances with liposomes as pharmaceutical carriers. Nat. Rev. Drug Discov. 2005, 4, 145-160. [CrossRef] [PubMed]

134. Goyal, P.; Goyal, K.; Kumar, S.G.V.; Singh, A.; Katare, O.P.; Mishra, D.N. Liposomal drug delivery systems-Clinical applications. Acta Pharm. 2005, 55, 1-25. [PubMed]

135. Al-Jamal, W.T.; Kostarelos, K. Liposomes: From a Clinically Established Drug Delivery System to a Nanoparticle Platform for Theranostic Nanomedicine. Acc. Chem. Res. 2011, 44, 1094-1104. [CrossRef] [PubMed] 
136. López-Sagaseta, J.; Malito, E.; Rappuoli, R.; Bottomley, M.J. Self-assembling protein nanoparticles in the design of vaccines. Comput. Struct. Biotechnol. J. 2016, 14, 58-68. [CrossRef]

137. Basha, G.; I Novobrantseva, T.; Rosin, N.; Tam, Y.Y.C.; Hafez, I.M.; Wong, M.K.; Sugo, T.; Ruda, V.M.; Qin, J.; Klebanov, B.; et al. Influence of Cationic Lipid Composition on Gene Silencing Properties of Lipid Nanoparticle Formulations of siRNA in Antigen-Presenting Cells. Mol. Ther. 2011, 19, 2186-2200. [CrossRef]

138. Chen, Y.; Zhu, X.; Zhang, X.; Liu, B.; Huang, L. Nanoparticles Modified With Tumor-targeting scFv Deliver siRNA and miRNA for Cancer Therapy. Mol. Ther. 2010, 18, 1650-1656. [CrossRef]

139. Ma, Y.; Zhuang, Y.; Xie, X.; Wang, C.; Wang, F.; Zhou, D.; Zeng, J.; Cai, L. The role of surface charge density in cationic liposome-promoted dendritic cell maturation and vaccine-induced immune responses. Nanoscale 2011, 3, 2307-2314. [CrossRef]

140. Tagami, T.; Foltz, W.D.; Ernsting, M.J.; Lee, C.M.; Tannock, I.F.; May, J.; Li, S.-D. MRI monitoring of intratumoral drug delivery and prediction of the therapeutic effect with a multifunctional thermosensitive liposome. Biomaterials 2011, 32, 6570-6578. [CrossRef]

141. Ren, L.; Chen, S.; Li, H.; Zhang, Z.; Ye, C.; Liu, M.; Zhou, X. MRI-visible liposome nanovehicles for potential tumor-targeted delivery of multimodal therapies. Nanoscale 2015, 7, 12843-12850. [CrossRef] [PubMed]

142. Kaasgaard, T.A.; Thomas, L. Liposomal cancer therapy: Exploiting tumor characteristics. Expert Opin. Drug Deliv. 2010, 7, 225-243. [CrossRef] [PubMed]

143. Kierstead, P.H.; Okochi, H.; Venditto, V.J.; Chuong, T.C.; Kivimae, S.; Fréchet, J.M.; Szoka, F.C. The effect of polymer backbone chemistry on the induction of the accelerated blood clearance in polymer modified liposomes. J. Control. Release 2015, 213, 1-9. [CrossRef] [PubMed]

144. Hatakeyama, H.; Akita, H.; Harashima, H. The Polyethyleneglycol Dilemma: Advantage and Disadvantage of PEGylation of Liposomes for Systemic Genes and Nucleic Acids Delivery to Tumors. Biol. Pharm. Bull. 2013, 36, 892-899. [CrossRef]

145. Kang, H.; O’Donoghue, M.B.; Liu, H.; Tan, W. A liposome-based nanostructure for aptamer directed delivery. Chem. Commun. 2009, 46, 249-251. [CrossRef]

146. Sonali, L.J.; Singh, R.P.; Singh, N.; Sharma, G.; Vijayakumar, M.R.; Koch, B.; Singh, S.; Singh, U.; Dash, D.; Pandey, B.L.; et al. Transferrin liposomes of docetaxel for brain-targeted cancer applications: Formulation and brain theranostics. Drug Deliv. 2016, 23, 1261-1271. [CrossRef]

147. Xu, H.; Paxton, J.; Wu, Z. Enhanced pH-Responsiveness, Cellular Trafficking, Cytotoxicity and Long-circulation of PEGylated Liposomes with Post-insertion Technique Using Gemcitabine as a Model Drug. Pharm. Res. 2015, 32, 2428-2438. [CrossRef]

148. Li, Y.; Liu, R.; Yang, J.; Shi, Y.; Ma, G.; Zhang, Z.; Zhang, X. Enhanced retention and anti-tumor efficacy of liposomes by changing their cellular uptake and pharmacokinetics behavior. Biomaterials 2015, 41, 1-14. [CrossRef]

149. Andresen, T.L.; Jensen, S.S.; Jørgensen, K. Advanced Strategies in Liposomal Cancer Therapy: Problems and Prospects of Active and Tumor Specific Drug Release. Prog. Lipid Res. 2005, 44, 68-97. [CrossRef]

150. Yu, B.; Tai, H.C.; Xue, W.; Lee, L.J.; Lee, R.J. Receptor-Targeted Nanocarriers for Therapeutic Delivery to Cancer. Mol. Membr. Biol. 2010, 27, 286-298. [CrossRef]

151. Zhu, L.; Kate, P.; Torchilin, V.P. Matrix Metalloprotease 2-Responsive Multifunctional Liposomal Nanocarrier for Enhanced Tumor Targeting. Acs Nano 2012, 6, 3491-3498. [CrossRef] [PubMed]

152. Maruyama, K. Intracellular targeting delivery of liposomal drugs to solid tumors based on EPR effects. Adv. Drug Deliv. Rev. 2011, 63, 161-169. [CrossRef] [PubMed]

153. Paliwal, S.R.; Paliwal, R.; Vyas, S.P. A review of mechanistic insight and application of $\mathrm{pH}$-sensitive liposomes in drug delivery. Drug Deliv. 2015, 22, 231-242. [CrossRef] [PubMed]

154. Murthy, R.S.R.; Karanth, H. pH-sensitive liposomes-principle and application in cancer therapy. J. Pharm. Pharmacol. 2007, 59, 469-483.

155. Xu, H.; Hu, M.; Yu, X.; Li, Y.; Fu, Y.; Zhou, X.; Zhang, D.; Li, J. Design and evaluation of pH-sensitive liposomes constructed by poly(2-ethyl-2-oxazoline)-cholesterol hemisuccinate for doxorubicin delivery. Eur. J. Pharm. Biopharm. 2015, 91, 66-74. [CrossRef] [PubMed]

156. Mo, R.; Sun, Q.; Xue, J.; Li, N.; Li, W.; Zhang, C.; Ping, Q. Drug Delivery: Multistage pH-Responsive Liposomes for Mitochondrial-Targeted Anticancer Drug Delivery (Adv. Mater. 27/2012). Adv. Mater. 2012, 24, 3659-3665. [CrossRef] 
157. Himanshu, P.; Radha, R.; Vishnu, A. Liposome and Their Applications in Cancer Therapy. Braz. Arch. Biol. Technol. 2016, 59, e16150477.

158. Hong, M.-S.; Lim, S.-J.; Oh, Y.-K.; Kim, C.-K. pH-Sensitive, SerumStable and Long-circulating Liposomes as a New Drug Delivery System. J. Pharm. Pharmacol. 2002, 54, 51-58. [CrossRef]

159. Ferreira, D.D.S.; Lopes, S.C.; Franco, M.S.; Oliveira, M.C. pH-sensitive liposomes for drug delivery in cancer treatment. Ther. Deliv. 2013, 4, 1099-1123. [CrossRef]

160. Ramishetti, S.; Leaf, H. Intelligent design of multifunctional lipid-coated nanoparticle platforms for cancer therapy. Ther. Deliv. 2012, 3, 1429-1445. [CrossRef]

161. Kaul, A.; Chaturvedi, S.; Attri, A.; Kalra, M.; Mishra, A.K. Targeted theranostic liposomes: Rifampicin and ofloxacin loaded pegylated liposomes for theranostic application in mycobacterial infections. Rsc Adv. 2016, 6, 28919-28926. [CrossRef]

162. Lozano, N.; Al-Ahmady, Z.S.; Beziere, N.S.; Ntziachristos, V.; Kostarelos, K. Monoclonal antibody-targeted PEGylated liposome-ICG encapsulating doxorubicin as a potential theranostic agent. Int. J. Pharm. 2015, 482, 2-10. [CrossRef] [PubMed]

163. Chang, J.-S.; Choi, M.-J.; Cheong, H.-S.; Kim, K. Development of Th1-Mediated CD8+ Effector T Cells by Vaccination with Epitope Peptides Encapsulated in pH-Sensitive Liposomes. Vaccine 2001, 19, 3608-3614. [CrossRef]

164. Sethuraman, V.A.; Lee, M.C.; Bae, Y.H. A Biodegradable pH-sensitive Micelle System for Targeting Acidic Solid Tumors. Pharm. Res. 2008, 25, 657-666. [CrossRef]

165. Liu, Y.; Feng, L.; Liu, T.; Zhang, L.; Yao, Y.; Yu, D.; Wang, L.; Zhang, N. Multifunctional pH-sensitive polymeric nanoparticles for theranostics evaluated experimentally in cancer. Nanoscale 2014, 6, 3231-3242. [CrossRef] [PubMed]

166. Li, Z.; Qiu, L.; Chen, Q.; Hao, T.; Qiao, M.; Zhao, H.; Zhang, J.; Hu, H.; Zhao, X.; Chen, D.; et al. pH-sensitive nanoparticles of poly(l-histidine)-poly(lactide-co-glycolide)-tocopheryl polyethylene glycol succinate for anti-tumor drug delivery. Acta Biomater. 2015, 11, 137-150. [CrossRef] [PubMed]

167. Kanapathipillai, M.; Brock, A.; Ingber, D.E. Nanoparticle Targeting of Anti-Cancer Drugs that Alter Intracellular Signaling or Influence the Tumor Microenvironment. Dvanced Drug Deliv. Rev. 2014, 79, 107-118. [CrossRef]

168. Zhang, Y.; Li, P.; Pan, H.; Liu, L.; Ji, M.; Sheng, N.; Wang, C.; Cai, L.; Ma, Y. Retinal-Conjugated pHSensitive Micelles Induce Tumor Senescence for Boosting Breast Cancer Chemotherapy. Biomaterials 2016, 83, $219-232$. [CrossRef]

169. Nishiyama, N.; Kataoka, K. Current state, achievements, and future prospects of polymeric micelles as nanocarriers for drug and gene delivery. Pharmacol. Ther. 2006, 112, 630-648. [CrossRef]

170. Wang, J.; Mao, W.; Lock, L.L.; Tang, J.; Sui, M.; Sun, W.; Cui, H.; Xu, D.; Shen, Y. The role of micelle size in tumor accumulation, penetration, and treatment. ACS Nano 2015, 9, 7195-7206. [CrossRef]

171. Cheng, J.; Ji, R.; Gao, S.-J.; Du, F.-S.; Li, Z.-C. Facile Synthesis of Acid-Labile Polymers with Pendent Ortho Esters. Biomacromolecules 2012, 13, 173-179. [CrossRef] [PubMed]

172. Zhao, X.; Liu, P.; Song, Q.; Gong, N.; Yang, L.; Wu, W.D. Surface charge-reversible polyelectrolyte complex nanoparticles for hepatoma-targeting delivery of doxorubicin. J. Mater. Chem. B 2015, 3, 6185-6193. [CrossRef] [PubMed]

173. Harashima, H.; Ito, E.; Akita, H.; Oishi, M.; Nagasaki, Y.; Futaki, S.; Harashima, H. A pH-sensitive fusogenic peptide facilitates endosomal escape and greatly enhances the gene silencing of siRNA-containing nanoparticles in vitro and in vivo. J. Control. Release 2009, 139, 127-132.

174. Fei, L.; Yap, L.-P.; Conti, P.S.; Shen, W.-C.; Zaro, J.L. Tumor targeting of a cell penetrating peptide by fusing with a $\mathrm{pH}$-sensitive histidine-glutamate co-oligopeptide. Biomaterials 2014, 35, 4082-4087. [CrossRef]

175. Li, M.; Lv, S.; Tang, Z.; Song, W.; Yu, H.; Sun, H.; Liu, H.; Chen, X. Polypeptide/doxorubicin hydrochloride polymersomes prepared through organic solvent-free technique as a smart drug delivery platform. Macromol. Bioence 2013, 13, 1150-1162. [CrossRef]

176. Elena, R.; Stefano, S.; Francesca, M.; Sara, B.; Elena, G.; Paolo, C. pH-responsive lipid core micelles for tumour targeting. Eur. J. Pharm. Biopharm. 2013, 83, 346-357.

177. Taghizadeh, B.; Taranejoo, S.; Monemian, S.A.; Moghaddam, Z.S.; Daliri, K.; Derakhshankhah, H.; Derakhshani, Z. Classification of stimuli-responsive polymers as anticancer drug delivery systems. Drug Deliv. 2015, 22, 145-155. [CrossRef] 
178. Yang, Y.Q.; Zhao, B.; Li, Z.D.; Lin, W.J.; Zhang, C.Y.; Guo, X.D.; Wang, J.F.; Zhang, L. pH-sensitive micelles self-assembled from multi-arm star triblock co-polymers poly( $\varepsilon$-caprolactone)-b-poly(2-(diethylamino)ethyl methacrylate)-b-poly(poly(ethylene glycol) methyl ether methacrylate) for controlled anticancer drug delivery. Acta Biomater. 2013, 9, 7679-7690. [CrossRef]

179. Gao, Y.; Li, Y.; Li, Y.; Yuan, L.; Zhou, Y.; Li, J.; Zhao, L.; Zhang, C.; Li, X.; Liu, Y. PSMA-mediated endosome escape-accelerating polymeric micelles for targeted therapy of prostate cancer and the real time tracing of their intracellular trafficking. Nanoscale 2015, 7, 597-612. [CrossRef]

180. Gillies, E.R.; Fréchet, J.M.J. A new approach towards acid sensitive copolymer micelles for drug delivery. Chem. Commun. 2003, 14, 1640-1641. [CrossRef]

181. Song, N.; Zhou, L.; Li, J.; Pan, Z.; He, X.; Tan, H.; Wan, X.; Li, J.; Ran, R.; Fu, Q. Inspired by nonenveloped viruses escaping from endo-lysosomes: A pH-sensitive polyurethane micelle for effective intracellular trafficking. Nanoscale 2016, 8, 7711-7722. [CrossRef] [PubMed]

182. Lee, Y.; Park, S.Y.; Mok, H.; Park, T.G. Synthesis, characterization, antitumor activity of pluronic mimicking copolymer micelles conjugated with doxorubicin via acid-cleavable linkage. Bioconjugate Chem. 2008, 19, 525-531. [CrossRef] [PubMed]

183. Ding, C.; Gu, J.; Qu, X.; Yang, Z. Preparation of Multifunctional Drug Carrier for Tumor-Specific Uptake and Enhanced Intracellular Delivery through the Conjugation of Weak Acid Labile Linker. Bioconjugate Chem. 2009, 20, 1163-1170. [CrossRef] [PubMed]

184. Bae, Y.; Nishiyama, N.; Fukushima, S.; Koyama, H.; Yasuhiro, M.; Kataoka, K. Preparation and biological characterization of polymeric micelle drug carriers with intracellular $\mathrm{pH}$-triggered drug release property: Tumor permeability, controlled subcellular drug distribution, and enhanced in vivo antitumor efficacy. Bioconjug. Chem. 2005, 16, 122-130. [CrossRef]

185. Zhou, Z.; Li, L.; Yang, Y.; Xu, X.; Huang, Y. Tumor targeting by pH-sensitive, biodegradable, cross-linked $\mathrm{N}$-(2-hydroxypropyl) methacrylamide copolymer micelles. Biomaterials 2014, 35, 6622-6635. [CrossRef]

186. Li, J.; Zhou, Y.; Li, C.; Wang, D.; Gao, Y.; Zhang, C.; Zhao, L.; Li, Y.; Liu, Y.; Li, X. Poly(2-ethyl-2oxazoline)-Doxorubicin Conjugate-Based Dual Endosomal $\mathrm{pH}$-Sensitive Micelles with Enhanced Antitumor Efficacy. Bioconjug. Chem. 2014, 26, 110-119. [CrossRef]

187. Varshosaz, J.; Hassanzadeh, F.; Sadeghi-Aliabadi, H.; Larian, Z.; Rostami, M. Synthesis of Pluronic ${ }^{\circledR}$ F127-poly (methyl vinyl ether-alt-maleic acid) copolymer and production of its micelles for doxorubicin delivery in breast cancer. Chem. Eng. J. 2014, 240, 133-146. [CrossRef]

188. Tang, R.; Ji, W.; Wang, C. Amphiphilic block copolymers bearing ortho ester side-chains: $\mathrm{pH}$-dependent hydrolysis and self-assembly in water. Macromol. Bioence 2010, 10, 192-201. [CrossRef]

189. Gregory, G. Incorporation of Poly(Ethylene Glycol) Lipid into Lipoplexes: On-Line Incorporation Assessment and Pharmacokinetics Advantages. Liposome Technol. 2006, 273-292.

190. Wu, Y.; Chen, W.; Meng, F.; Wang, Z.; Cheng, R.; Deng, C.; Liu, H.; Zhong, Z. Core-crosslinked pH-sensitive degradable micelles: A promising approach to resolve the extracellular stability versus intracellular drug release dilemma. J. Control. Release 2012, 164, 338-345. [CrossRef]

191. Peeler, D.J.; Thai, S.N.; Cheng, Y.; Horner, P.J.; Sellers, D.L.; Pun, S.H. pH-sensitive polymer micelles provide selective and potentiated lytic capacity to venom peptides for effective intracellular delivery. Biomaterials 2019, 192, 235-244. [CrossRef] [PubMed]

192. Xiong, J.; Meng, F.; Wang, C.; Cheng, R.; Liu, Z.; Zhong, Z. Folate-conjugated crosslinked biodegradable micelles for receptor-mediated delivery of paclitaxel. J. Mater. Chem. 2011, 21, 5786-5794. [CrossRef]

Publisher's Note: MDPI stays neutral with regard to jurisdictional claims in published maps and institutional affiliations.

(C) 2020 by the authors. Licensee MDPI, Basel, Switzerland. This article is an open access article distributed under the terms and conditions of the Creative Commons Attribution (CC BY) license (http://creativecommons.org/licenses/by/4.0/). 